\title{
NEXUS OF BORN GLOBAL ENTREPRENEURSHIP FIRMS AND ECONOMIC DEVELOPMENT IN NIGERIA
}

\author{
Olufemi Amos Akinbola ${ }^{1, \mathrm{a}, *}$, Bisayo Oluwatosin Otokiti², \\ Omolola Sariat Akinbola ${ }^{3}$ and Sekinat Arike Sanni ${ }^{4}$ \\ ${ }^{1}$ Department of Business Administration, Federal University of Agriculture, Abeokuta, Nigeria \\ *akinbolaoa@funaab.edu.ng \\ ${ }^{2}$ Department of Business and Entrepreneurship, Kwara State University, Nigeria \\ ${ }^{3}$ Department of Business Administration, Faculty of Management Sciences, University of Lagos,
}

Cite as: Akinbola, O.A., Otokiti, B.O., Akinbola, O.S., Sanni, S.A. (2020). Nexus of born global entrepreneurship firms and economic development in Nigeria. Ekonomicko-manazerske spektrum, 14(1), 52-64.

Available at: dx.doi.org/10.26552/ems.2020.1.52-64

\begin{abstract}
Born Global entrepreneurship firms have gained a substantial essential foundation of international knowledge and experience as typically considered by traditional multinational enterprises (MNEs). In this sense, the traditional views regarding a corporate internationalisation are being challenged by Born Globals. The word "born global," has been used to refer to firms that successfully contributed to international business through their export of products and services consistently. The objectives of the study are to assess educational initiatives program of born global firms with respect to human capital and also the relationship between social welfare and social capital. Some organization and corporate management believes that the development of the community they operate may sometimes aggravate overhead costs resulting in excess of financial liabilities for the enterprise and often does not provide basis for corporate social responsibilities in the environment of business operations. The population of this study included all employees of qualified firms in the category of born global firms operating in Nigeria with respect to Tecno mobile company and Jumia Nigeria limited which operate in Lagos State, Nigeria. The sample consists of three hundred and sixty (360) employees. The results of this study are consistent with the opinion that improvement of people's social welfare can also contribute to the improvement of social capital. In conclusion, the study recommends that; Government should encourage born global firms to improve communal development in the country by providing enabling environment for their operations.
\end{abstract}

Keywords: Born Global firms, Economic Development, Communal development, Social Welfare, Social Capital

JEL Classification: L26, M1, M19

\section{Introduction}

In the span of two to three years after its creation, the word "born global," has been used to refer to firms that successfully contributed to international business through their export of products and services. The phenomenon was noted in the Australian Manufacturing Council's joint project, in which it was noted that international companies born internationally are competitive not only in their international business but also compete with giant companies. Crick (2009) also stressed that these firms contribute both to the country's macroeconomic 
factors and generate income, boost economic growth, export and employment. Born Global managers begin with a global perspective and build resources set at the company's strategy and organisation's level of culture that will contribute to internationalization and growth at an early stage in a wide range of foreign markets. Also, Kontinen and Ojala (2010), Martin et al. (2017), affirms thatInternationalization of firms has traditionally been a gradual and incremental process, firms concentrated in their home country and internationalized over a long time, some firms have operated locally for 7,10,15 and even 20 years before internationalizing. However, international entrepreneurship literature documents that some firms internationalized early, some internationalized in less than 3 years after creation, while some even began exporting since their creation, with most of these firms usually having a global orientation since inception. This class of firms are called international new venture or born global firms. Born global firms differ from the traditional form of firms' internationalization that is characterized by gradual or incremental entry into a foreign market and usually operates locally for over 6 years before internationalizing. Born global firms on the other hand internationalize rapidly and they usually have an international orientation from early stage of start-up.

\section{Statement of the problem}

First research was carried out on established worldwide firms to understand their process and pattern of internationalization. The internationalization cycle of born global companies has been focused on by Sulina and Manjit (2014), Cavusgil and Knight (2009) and Di Gregorio, Musteen and Thomas (2008). The authors later based their work better on and overcome the challenges facing these emerging global companies (Luostarinen and Gabrielsson, 2002) than their organizational characteristics. Nevertheless, studies have shown that small and medium-sized companies make a significant contribution in terms of economic growth and even foreign business to developing countries. (Hashai, 2011) Notwithstanding this, a number of born global companies still do not standardize their operations and do not have any effect on their society and culture. Some management believes that the development of the community they operate in has high costs and does not provide for corporate social responsibilities. This research remedied these shortcomings by exploring the benefits, consequences and influence on shared social capital of born world businesses. With reference to these, the study intends to ascertain through the hypotheses as stated in null forms;

H01: Educational initiatives has no significant effect on human capital

H02: There is no significant relationship between social welfare and social capital

\section{Globalization and Born Global companies}

Rapid economic shifts and increasing competition, particularly in consumer markets, causes goods to have shorter life-cycles, which demands that new products be produced constantly. To be able to extend the useful lives for their goods, businesses must constantly look for new markets. (Coviello (2006), Autio et al. (2000) and De Clercq et al. (2012)) Various reasons influence internationalization of small and medium-sized companies. Firstly, the obstacles to internationalization have been reduced by fewer customs checks and better communication and normalization. Second, the process of internationalization for smaller businesses has reflected rapid changes. The foundation begins even earlier than before. (Cancino and Coronado, 2014) Jones et al. (2011) point that a company's success relies on the dream of the business manager. Is it easy to understand the picture of the environment? There are many who believe it is a nuanced image. In a Born Global company, Rasmussen et al. (2000) and Garcia-Cabrera et al. (2017) point that the entrepreneur makes sense for the 
environmental situation. Due to his past experience and knowledge he is constantly ready to reconsider the situation through new experiences. So long as it is black, the global factory is the very antithesis of all colours. Many products can be outsourced, including human resources. There is however a chance of a company losing its core skills (Karra, Phillips and Tracey, 2008).

\section{Social Life Cycle Theory}

The theory of the social life cycle is based upon the predictable evolutionary course of social issues (Andriof and Waddock, 2002). The number of stages or cycles through which a question evolves depends on the author. For instance, three to four stages were identified in Andriof and Waddock (2002). Most social theorist agree that social problems have pushed forward from a sudden age of knowledge and demands of intervention to a period of time where existing standards to manage the topic are integrated in a company's regular workings (Theorists on social issues). In The Social Challenge to Business, Ackerman (1975) has developed the most influential versions of the life cycle theory. He discussed many examples of the creation of corporate approaches to social issues. Coviello and Munro (1995), Mohammed et al. (2017) reveals in general, the reactivity of corporations to social issues is advanced via a three-phase path: policy, learning and commitment. The MNEs interviewed have improved their responsibilities towards their host communities. From the description above, Akinbola, Kowo, Akinbola and Ibidunni (2018) indicates four general trends: (a) an increased organizational commitment to social action; (c) a transition from mere lip service to concrete activity; (c) an increased organizational know-how with and ways to tackle social issues; and (d) a more standardized response to social and environmental problems.

\section{Empirical framework}

After carrying out research there, Ahmad, O'Regan and Ghobadian (2003) conclude that environmental management could play a significant role in the impovement of corporate performance. Windsor (2006) measured various companies within China using an index system of assessment and found that the organization with higher scores performs very well. Cheng and $\mathrm{Yu}$ (2008) showed the positive relationship between CSR and portfolio performance and was also found for Lockett, Moon and Visser (2006). This positive relationship has been attributed to the good image of the company that makes CSR preferable to such companies. According to Moen and Servai (2002), Rodriguez-Serrano and MartinArmario (2017), the good CSR conduct benefits the company's reputation. Furthermore, at the same time, very often in developing countries, governments are either unable because they are too weak or unable, because they are too corrupt, to address many of the problems inherent in that country's social fabric, and then those same people who accuse businesses of getting all that power turn around almost torturously and tell the only people who can act. (Sulina and Manjit, 2014).

\section{Methodology}

The method adopted for the conduct of this research is the survey with insight to ex-post facto approach as provided by Bryman and Bell (2007) for a study of this nature. Interviewees' opinion was gathered by administering structured questionnaire. The population of this study included all employees in Tecno mobile company Nigeria head office and Jumia Nigeria limited which operate in Lagos State Nigeria. The sample consists of three hundred and sixty (360) employees. 


\section{Results}

The study questionnaire remained issued toward three hundred and sixty (360) personnel reflecting the sample size defining the selected study population Two hundred and seventy seven (277) questionnaires of $77 \%$ were returned and ninety three (93) questionnaires of $23 \%$ remained unreturned.

\section{Frequency Distribution of the Interviewee' Demographic Characteristics}

The frequency distribution of demographic features of the interviewee is outlined in table 1 below. The table shows 196 (70.8 percent) of two hundred and seventy seven (277) interviewee are male while 81 (29.2 percent) are female. This means we've more male interviewee in the survey than male interviewee. Moreover, 122(44\%) of the two hundred and seventy seven (277) interviewee are single while $128(46.2 \%)$ are married and 27(9.7\%) are neither married nor single; this implies that most interviewee are married. Again, out of the two hundred and seventy-seven (277) respondents, $29(10.5 \%)$ are 51 years and above, 48 $(17.3 \%)$ are between 41 and 50 years of age, $114(41.2 \%)$ are between 31 and 40 years, and $86(31 \%)$ are between 21 and 30 years. By implication most of the respondents are between the age of 31 and 40 years. There are also 62 holders of M.SC and M.BA (22.4\%), 124 holders of HND / BSc (44.8\%), 48 holders of SSCE (17.3\%) and 43 holders of other certificates $(15.5 \%)$. That means high HND / BSc education credentials for the interviewee. Most specifically, out of the two hundred and seventy seven (277) interviewee, 46 (16.6 percent) are artisan industry employees; 122 (44 percent) are service industry employees; 75 (327.1 percent) are manufacturing industry employees, while 3 (1.5 percent) do not identify their business. It means we have more workers in the survey as interviewee from the service industry. Finally, out of the 277 respondents, 161 (58.1\%) are Christians; 80 (28.9\%) practices Islam; $36(13 \%)$ belongs to the other religion. By implication, we have more Christians in the sample.

Table 1: Frequency distribution of the interviewee' demographic characteristics

\begin{tabular}{lllll}
\hline Characteristics & Category & Frequency & Percentage & Cumulative percent \\
\hline \multirow{2}{*}{ GENDER } & Male & 196 & 70.8 & 70.8 \\
& Female & 81 & 29.2 & 100 \\
RELIGION & Christianity & 161 & 58.1 & 58.1 \\
& Islamic & 80 & 28.9 & 87 \\
& Others & 36 & 13 & 100 \\
EDUCATIONAL QUALIFICATIONS & SSCE & 48 & 17.3 & 17.3 \\
& BSC/HND & 124 & 44.8 & 62.1 \\
& MSC/MBA & 62 & 22.4 & 84.5 \\
& OTHERS & 43 & 15.5 & 100 \\
AGE BRACKET & $21-30$ & 86 & 31 & 31 \\
& $31-40$ & 114 & 41.2 & 72.2 \\
& $41-50$ & 48 & 17.3 & 89.5 \\
INDUSTRY & 51 AND Above & 29 & 10.5 & 100 \\
& Manufacturing & 75 & 27.1 & 27 \\
& Service & 122 & 44 & 71.1 \\
& Artisan & 46 & 16.6 & 87.7 \\
MARITAL STATUS & Others & 34 & 12.3 & 100 \\
& Married & 128 & 46.2 & 46.2 \\
& Single & 122 & 44 & 90.3 \\
\hline
\end{tabular}

Source: Author's Fieldwork Computation (2019) 


\section{Descriptive Statistics of the Interviewee' Perceptions}

The Descriptive Statistics of the Respondents' Perceptions is presented in table 2 below. Concerning, we have information from 277 respondents; the range of Educational initiatives (EI) is from 3.5 to 5 points, with a mean of 4.35 and standard deviation of 0.45 . By implication, the respondents, on average, strongly agreed with questions on Educational Initiatives (EI). Concerning Social Welfare (SW), we have information from 277 respondents; the range of Social Welfare (SW) is from 3.4 to 4.8 points, with a mean of 4.25 and standard deviation of 0.43 . By implication, the respondents, on average, agreed with questions on Social Welfare (SW). Basic Social Amenities Provision, we have information from 277 respondents; the range of Basic Social Amenities Provision is from 2.8 to 5 points, with a mean of 4.18 and standard deviation of 0.50. By implication, the respondents are, on average, strongly agreed with questions on Basic Social Amenities Provision. Concerning Human Capital, we have information from 277 respondents; the range of Human Capital is from 3 to 5 points, with a mean of 4.23 and standard deviation of 0.45 . By implication, the respondents, on average, strongly agreed with questions on Human Capital. Concerning Social Capital, we have information from 227 respondents; the range of Social Capital is from 2.8 to 4.8 points, with a mean of 4.23 and standard deviation of 0.44 . By implication, the respondents, on average, strongly agreed with questions on Social Capital.

Table 2: Descriptive statistics of respondent perspective

\begin{tabular}{llllll}
\hline & $\mathrm{N}$ & Minimum & Maximum & Mean & Std. Deviation \\
\hline Educational Initiatives & 277 & 3.00 & 5.00 & 4.3538 & .45639 \\
Social Welfare & 277 & 3.40 & 4.80 & 4.2563 & .43138 \\
Human Capital & 277 & 3.00 & 5.00 & 4.2390 & .45833 \\
Social Capital & 277 & 2.80 & 4.80 & 4.2339 & .44217 \\
Valid N (listwise) & 277 & & & & \\
\hline
\end{tabular}

Source: Author's Fieldwork Computation (2019)

The hypotheses of the study are: (1) Educational initiatives have no significant effect on human capital. (2) There is no significant relationship between social welfare and social capital. To investigate these hypotheses and arrive at the objectives of the research, multiple regression analysis was used. Multiple regression is centered on correlation but permits a further advanced evaluation of the interconnections amongst a set of variables. It creates a quantity of assumptions around the data which are normality that believed that the dependent variable is naturally distributed (i.e. Communal Social Capital), multicollinearity that believed that the independent variables (Born global firms) are not well interrelated, also Homoscedasticity which believed that the difference amongst interpretations is equal and linearity which believed that the connection existing between dependent and independent variables is linear.

\section{Test of Normality}

It is possible to draw a normal curve in order to verify the normality of the dependent variable (i.e. Human Capital and Social Capital). The typical output values for FIRMSs are shown in Figures 1 to 2 . Many parametrical statistics assume that the results of each variable are normally distributed (i.e. follow the usual curve form). In this study, the scores are fairly normally distributed, with most scores in the middle tapering towards extremes. 
Figure 1: Historgram of supposed human capital scores

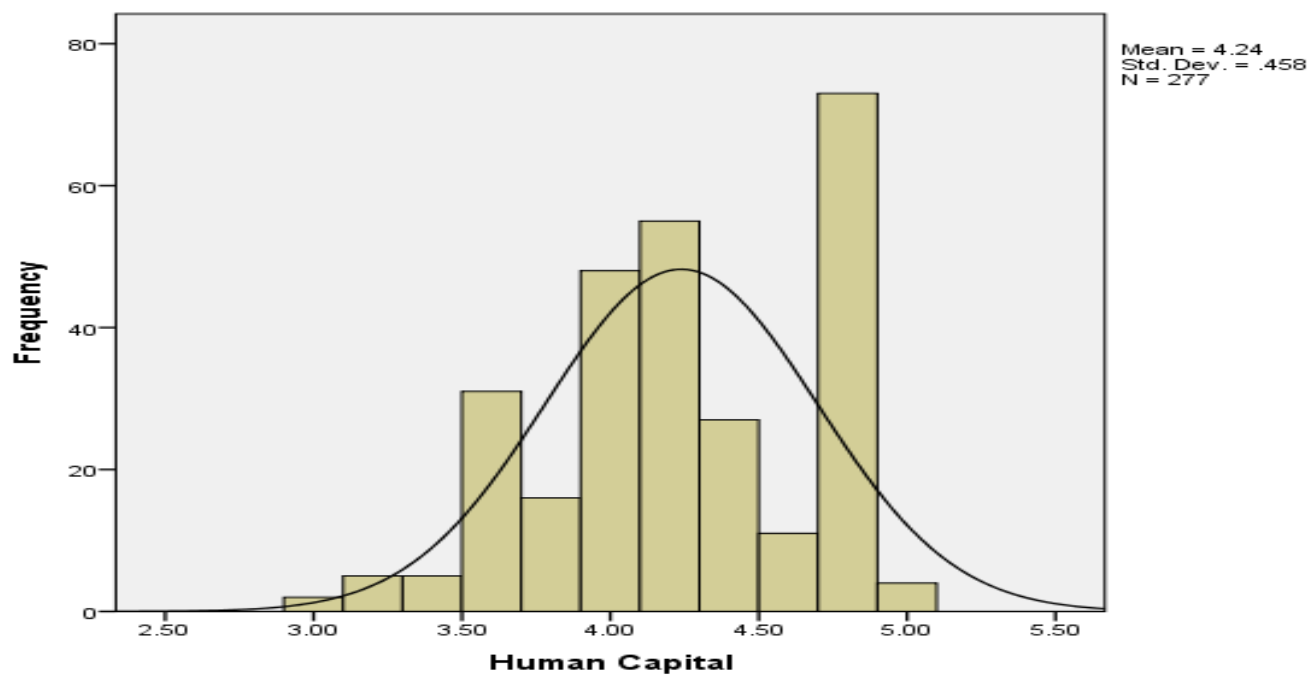

Source: Author's Fieldwork Computation (2019)

Figure 2: Historgram of supposed social capital scores

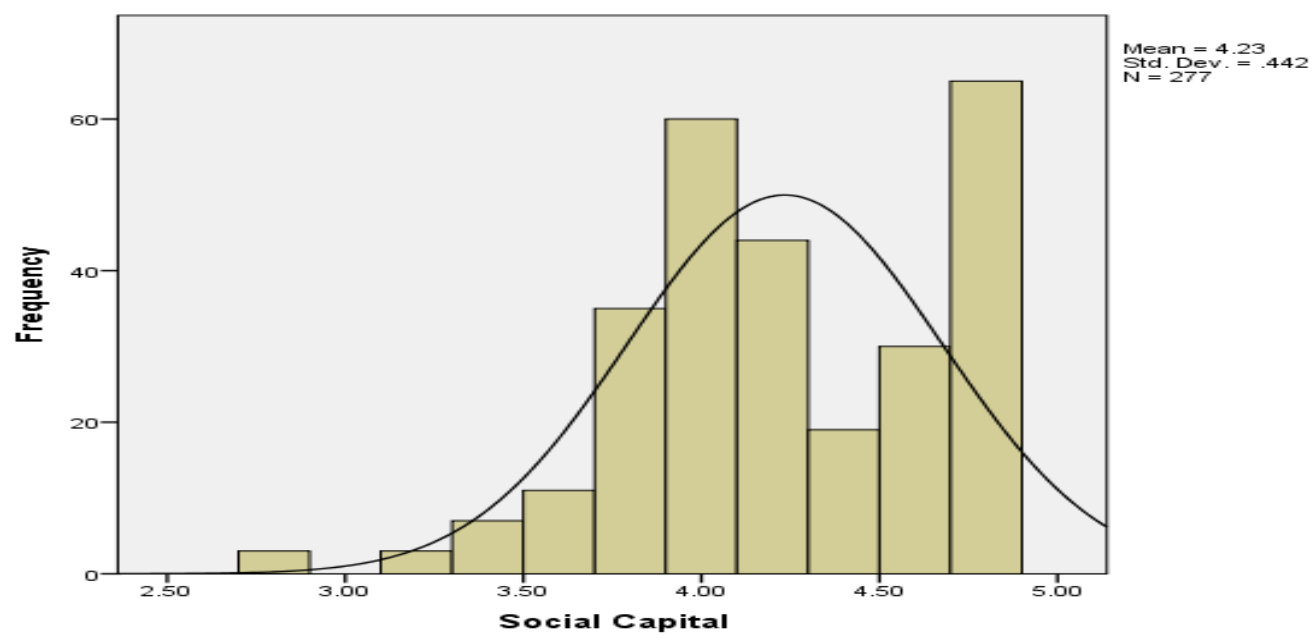

Source: Author's Fieldwork Computation (2019)

The bivariate analysis was performed in Table 3 below to test for multicolinearity. The average correlation in the table was 0.413 . The problem of multi-country lines among variables (Educational Initiatives and Social Welfare) shows little. Therefore, all the variables have been held.

Table 3: Correlations

\begin{tabular}{lllll}
\hline & & $\begin{array}{l}\text { Educational } \\
\text { Initiatives }\end{array}$ & Social Welfare & $\begin{array}{l}\text { Basic Social } \\
\text { Amenities } \\
\text { Provision }\end{array}$ \\
\hline \multirow{3}{*}{ Educational Initiatives } & Pearson Correlation & 1 & $.734^{* *}$ & $.538^{* *}$ \\
& Sig. (2-tailed) & & .000 & .000 \\
& $\mathrm{~N}$ & 277 & 277 & 277 \\
Social Welfare & Pearson Correlation & $.734^{* *}$ & 1 & $.652^{* *}$ \\
& Sig. (2-tailed) & .000 & & .000 \\
& $\mathrm{~N}$ & 277 & 277 & 277 \\
\hline
\end{tabular}

Source: Author's Fieldwork Computation, 2019 


\section{Test of Homoscedasticity and Linearity for Hypothesis one}

In order to test the uniformity and linearity of relations between dependent variables (i.e Communal Social Capital) and independent variables (i.e., Born Global Firms), a scatter plot was created The results of the scatter plots are shown in Figs 3 and 4. The findings below show that the variables are well balanced and positive.

Figure 3: Scatter Plot of Supposed Educational Initiatives and Human Capital Scores

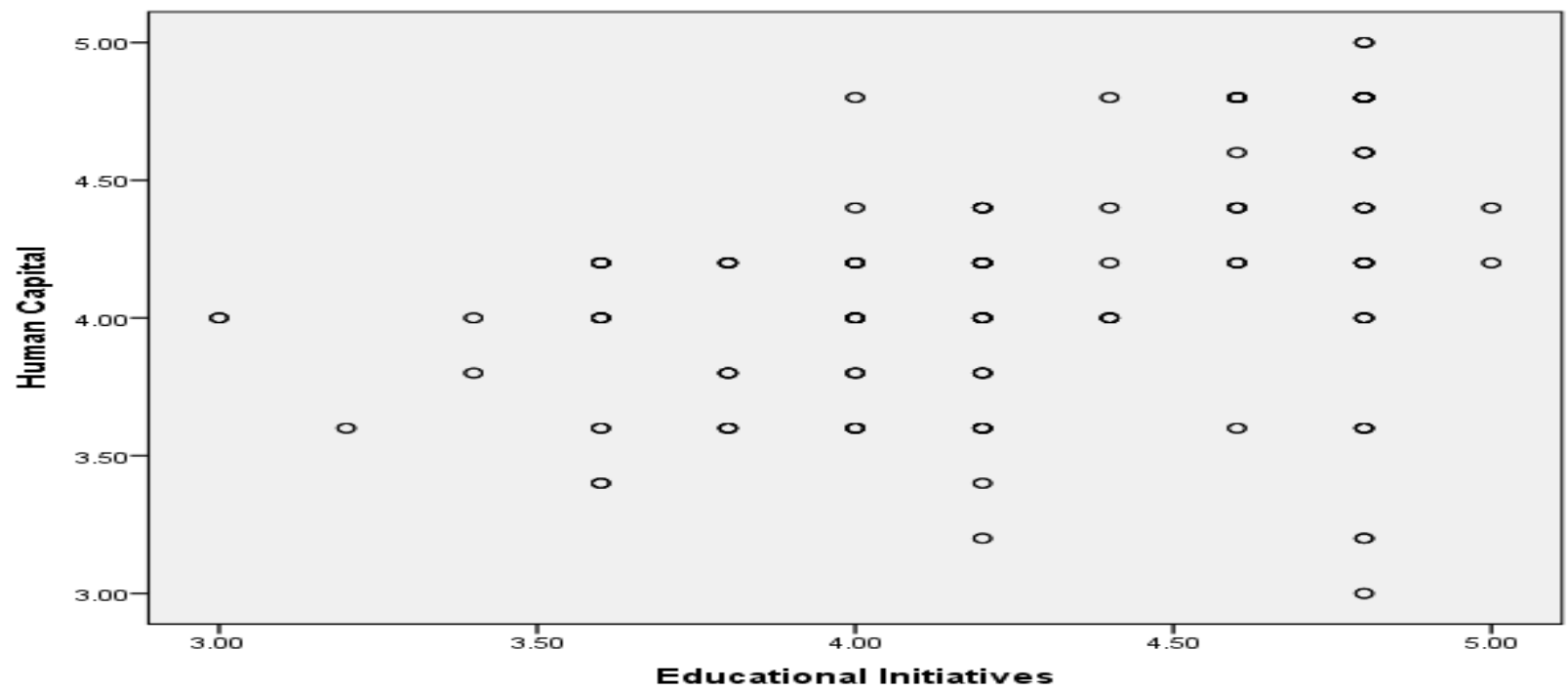

Source: Author's Fieldwork Computation, (2019)

Figure 4: Scatter Plot of Supposed Social Welfare and Human Capital Scores

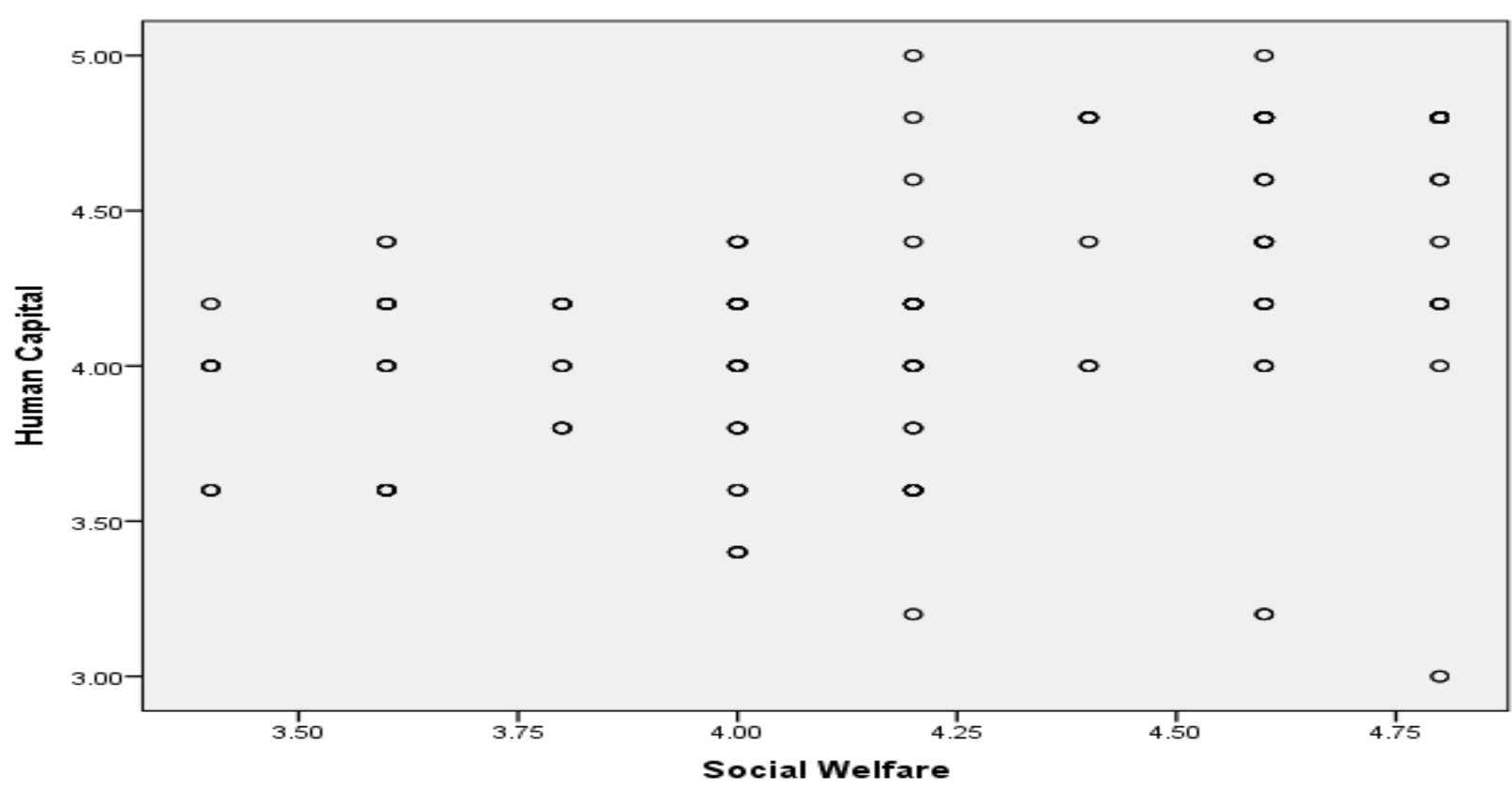

Source: Author's Fieldwork Computation (2019) 


\section{Test of Hypothesis One}

Ho1 Educational Initiatives and Social Welfare do not significantly affect Born Global Firms. Standard multiple regression was used to discover the outcomes of Educational Initiatives and Social Welfare on Born Global Firms. Initial analyses were done to make sure there is no violation of natural, multilinear assumptions. The regression result as shown in Table 4: ANOVA indicate that the F test was 10.619 which was significant at $5 \%[\mathrm{p}<.000]$. the model was well defined. This showed.

Table 4: ANOVA test

\begin{tabular}{|c|c|c|c|c|c|c|}
\hline \multicolumn{7}{|c|}{ ANOVA $^{a}$} \\
\hline \multirow[t]{2}{*}{ Model } & & Sum of Squares & Df & Mean Square & $\mathrm{F}$ & Sig. \\
\hline & Regression & 31.857 & 3 & 10.619 & 110.980 & $.000^{\mathrm{b}}$ \\
\hline \multirow[t]{2}{*}{1} & Residual & 26.122 & 273 & .096 & & \\
\hline & Total & 57.979 & 276 & & & \\
\hline \multicolumn{7}{|c|}{ a. Dependent Variable: Human Capital } \\
\hline
\end{tabular}

Source: Author's Fieldwork Computation (2019)

Furthermore, the regression results as found in Table 5: Model description indicates a significant 54.9 percent ranking in the $\mathrm{R}$ square. This means that around 19,3 percent of the difference in supposed FIRMS performance was explained by the model (including Educational Initiative and Social Welfare).

Table 5: Model description

\begin{tabular}{|c|c|c|c|c|}
\hline \multicolumn{5}{|c|}{ Model Summary } \\
\hline Model & $\mathrm{R}$ & R Square & Adjusted R Square & $\begin{array}{l}\text { Std. Error of the } \\
\text { Estimate }\end{array}$ \\
\hline 1 & $.741^{\mathrm{a}}$ & .549 & .545 & .30933 \\
\hline
\end{tabular}

Source: Author's Fieldwork Computation (2019)

The regression results as listed in Table 6: Regression coefficients test the second hypothesis of this study, in particular. Based on its performance, the supposed Educational Initiative was positively related to the supposed Social Capital in a way that resulted in an increase of approx. 0.177 unit in the Social Capital figures of firms, statistical significance 1 per cent by the value $\mathrm{p}(0.0)$ Overall, there was a positive connection between supposed social welfare and suppose social capital of firms that led to an increase of about 0.059 units of alleged social welfare by $1 \%(0.069)$ in allegedly firms. The conclusion acknowledged the zero hypothesis. Thus, the Educational initiative approach and the Human Capital of firms did not have any connection.

Table 6: Regression coefficients

\begin{tabular}{|c|c|c|c|c|c|c|}
\hline \multicolumn{7}{|c|}{ Coefficients $^{\mathrm{a}}$} \\
\hline \multirow{2}{*}{\multicolumn{2}{|c|}{ Model }} & \multicolumn{2}{|c|}{ Unstandardized Coefficients } & $\begin{array}{l}\text { Standardized } \\
\text { Coefficients }\end{array}$ & $\mathrm{T}$ & Sig. \\
\hline & & B & Std. Error & Beta & & \\
\hline \multirow{3}{*}{1} & (Constant) & .994 & .199 & & 5.006 & .000 \\
\hline & Educational Initiatives & .177 & .060 & .176 & 2.921 & .004 \\
\hline & Social Welfare & .059 & .071 & .056 & .837 & .404 \\
\hline \multicolumn{7}{|c|}{ a. Dependent Variable: Human Capital } \\
\hline
\end{tabular}

Source: Author's Fieldwork Computation (2019) 
Base on the analysis beneath, a strong, positive correlation appears to exist between the variables. Interviewee who are strongly influenced by the Educational Initiatives, and Social Welfare experience low growth factor rates. On the other hand, companies which are less impacted by Educational Initiatives, and Social Welfare have high growth rates. No signal of a curvilinear relationship (linearity check) is given, and the scatter plot display a justly uniform cigar shape beside its length (homoscedasticity check).

Figure 5: Scatter Plot of Supposed educational initiatives and social capital Scores

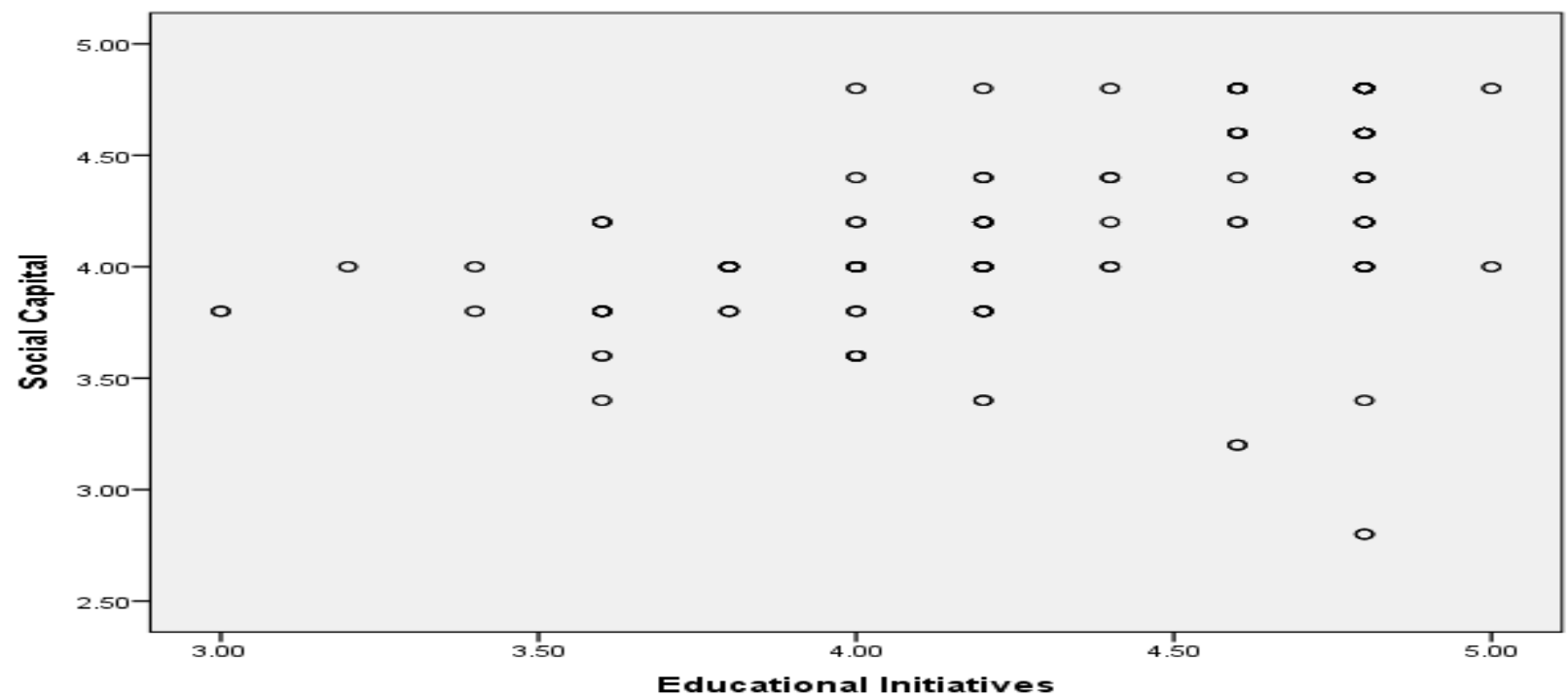

Source: Author's Fieldwork Computation (2019)

Figure 6: Scatter Plot of Supposed social welfare and social capital Scores

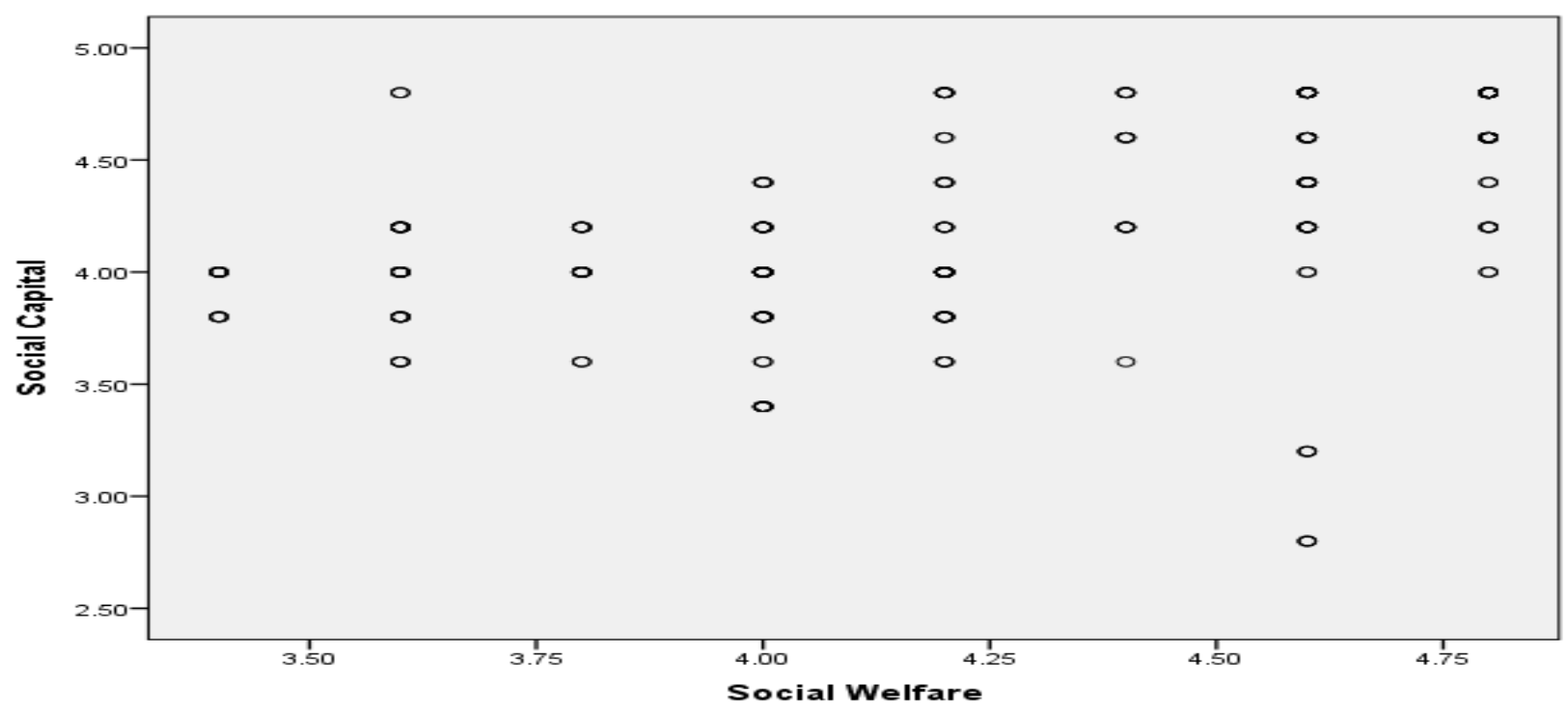

Source: Author's Fieldwork Computation (2019)

\section{Test of Hypothesis Two}

Ho2: Educational Initiatives, and Social Welfare does not significantly affect FIRMSs' Growth. The impact of Educational Initiatives, Social Welfare, on the growth of FIRMSs has been studied through a standard multiple regression. Preliminary analysis were carried out to ensure that there was no violation of the principles of normality, multicollinearity, 
homoscedasticity and linearity. The regression result, as contained in Table 7: ANOVA test, shows that the F-test was $64.414 \mathrm{p}<.011$ ] significant at 5\%. The model has been well defined. This showed.

Table 7: ANOVA test

\begin{tabular}{lllllll}
\hline \multicolumn{2}{l}{ ANOVA $^{\mathbf{a}}$} & \multicolumn{3}{l}{} \\
\hline Model & Sum of Squares & Df & Mean Square & F & Sig. \\
& Regression & 22.365 & 3 & 7.455 & 64.414 & $.000^{\mathrm{b}}$ \\
1 & Residual & 31.596 & 273 & .116 & & \\
\multicolumn{2}{l}{ a. Dependent Variable: Social Capital } & 276 & & \\
b. Predictors: (Constant), Educational Initiatives, Social Welfare \\
\hline
\end{tabular}

Source: Author's Fieldwork Computation, 2019

In addition, the regression results of the model summary table 8 indicates a value of $26.6 \mathrm{p}$ ercent for R square. That is, the pattern (which includes Educational Initiatives and Social Welfare) explained about 64.4 per cent of the variance in supposed firms Social Capital.

Table 8: Model description

\begin{tabular}{|c|c|c|c|c|}
\hline \multicolumn{5}{|c|}{ Model Summary } \\
\hline Model & $\mathrm{R}$ & R Square & Adjusted R Square & $\begin{array}{l}\text { Std. Error of the } \\
\text { Estimate }\end{array}$ \\
\hline 1 & $.644^{\mathrm{a}}$ & .414 & .408 & .34020 \\
\hline
\end{tabular}

Source: Author's Fieldwork Computation, 2019

The regression results as listed in Table 9: Regression coefficients test the second hypothesis of this study, in particular. Based on its performance, the supposed Educational Initiatives was positively related to the supposed Social Capital of firms in a way that resulted in an increase of approx. 0.267 unit in the supposed Social Capital figures of firms, statistical significance 1 per cent by the value $\mathrm{p}(0.0)$ Overall, there was a positive connection between supposed Social Welfare and suppose growth of small and medium-sized enterprises that led to an increase of about 0.137 units of alleged diversification strategies by $1 \%(0.000)$ in allegedly small-and medium-sized enterprises. The conclusion acknowledged the zero hypothesis. Thus, the diversification approach and the growth of small and medium-sized companies did not have any connection.

Table 9: Regression coefficients

\begin{tabular}{|c|c|c|c|c|c|c|}
\hline \multicolumn{7}{|c|}{ Coefficients $^{\mathrm{a}}$} \\
\hline \multirow{2}{*}{\multicolumn{2}{|c|}{ Model }} & \multicolumn{2}{|c|}{ Unstandardized Coefficients } & \multirow{2}{*}{$\begin{array}{l}\text { Standardized } \\
\text { Coefficients } \\
\text { Beta }\end{array}$} & \multirow[t]{2}{*}{$\mathrm{T}$} & \multirow[t]{2}{*}{ Sig. } \\
\hline & & $\mathrm{B}$ & Std. Error & & & \\
\hline \multirow{3}{*}{1} & (Constant) & 1.279 & .218 & & 5.856 & .000 \\
\hline & Social Welfare & .137 & .078 & .134 & 1.751 & .003 \\
\hline & Educational Initiatives & .267 & .067 & .275 & 4.008 & .000 \\
\hline & adent Variable: Social C & & & & & \\
\hline
\end{tabular}

Source: Author's Fieldwork Computation (2019) 


\section{Discussion}

\section{Discussion of Findings of Hypothesis One}

The findings of this study revealed a positive relationship between educational initiatives and human capital, so that educational initiatives have a significant impact on the firm's human capital. Diagnoses of student education programs supports companies and customized and personalized learning approaches. The result of this study resonates with Amoros et al. (2012), Pitan and Adedeji (2012) with a view that schooling and education makes people more competitive and increases an educated worker's marginal product compared to an uneducated worker. To conclude, companies will now believe that educational initiatives are an important instrument for effective human capital.

\section{Discussion of Findings of Hypothesis Two}

The results of this study are consistent with (Yu et al., 2011; Sulina and Manjit, 2014) of opinion that improvement of people's social welfare can also contribute to the improvement of social capital. Based on this result, there is a positive relationship between social welfare and social capital which is important to effective and efficient social capital. In conclusion, this research is consistent with previous expert researches which have found a positive relationship between social welfare and social capital.

\section{Conclusion and Recommendations}

In addition, this study has provided the results with a detailed description of the views of workers on the value of community development education, social welfare, and fundamental social facilities. The limitations of this study were that outcomes were presented based on the perspectives of most of the main employees. Instead, a combination or comparison should have been made with other players involved in community development. In order to successfully handle community growth, problems in education programs, social welfare and the provision of basic social services are anticipated and should be closely examined, as well as those aspects that are crucial to the success of the programme. The following recommendations were made;

i. The problems in educational programs, social welfare and basic social services provision relationship are anticipated and should be closely examined in order to successfully manage community social capital, and those factors that are critical to the success of their relationship should be recognized.

ii. The government is required to use the findings to enhance and improve the community-based social capital in the country by forcing all born global businesses to contribute to the community and environment's social capital through development in the educational, social, and basic social services fields.

iii. Such new results should also be used by multinational companies to develop and enhance their society and climate. In the growth of societies, it helps to boost people's social well-being and enhance the company's public will and organisation.

\section{References}

Ackerman, R.W. (1975). The Social Challenge to Business. Cambridge, MA: Harvard University Press.

Ahmad, S.J., O'Regan, N. and Ghobadian, A. (2003). Managing for performance: Corporate responsibility and internal stakeholders. International Journal of Business Performance Management, 5(2-3), pp. 141-153. 
Akinbola, O.A, Sanni, S.A. and Akinbola, O.S. (2018). Appraisal of Entrepreneurship Capacity Programs and Internationalization of Small and Medium Enterprises in Nigeria. Acta Universitatis Danubius. Oeconomica, 14(6), pp. 72-89.

Akinbola, O.A., Kowo, S.A., Akinbola, O.S. and Ibidunni, S. (2018). Moderating influence of corporate social responsibility on organizational performance of brewing transnational corporation. International Journal of Data and Network Science, 2(2), pp. 49-56.

Amoros, J.E., Etchebarne, S. and Felzensztein, C. (2012). International entrepreneurial firms: A LatinAmerican perspective. Esic Market Economic and Business Journal, 43(3), pp. 497-512.

Andriof, J. and Waddock, S. (2002). Unfolding Stakeholder Engagement. J. Andriof and S. Waddock, B. Husted and S. Sutherland (eds.), Unfolding Stakeholder Thinking. Sheffield, UK Greenleaf, Publishing.

Autio, E., Sapienza, H. and Almeida, J. (2000). Effects of age at entry, knowledge intensity, and imitability on international growth. Academy of Management Journal, 43(5), pp. 909-924.

Bryman, A. and Bell, E. (2007). Business Research Methods. 2nd ed. New York: Oxford University Press.

Cancino, C.A. and Coronado, F.C. (2014). Exploring the determinants of born global firms in Chile. Academia Revista Latinoamericana de Administracion, 27(13), pp. 386-401.

Cavusgil, S.T. and Knight, G. (2009). Born Global Firms: A New International Enterprise. New York, NY: Business Expert Press.

Cheng, H. and Yu, C.J. (2008). Institutional pressures and initiation of internationalization: Evidence from Taiwanese small-and-medium-sized enterprises. International Business Review, 17(3), pp. 331-348.

Coviello, N. (2006). The network dynamics of international new ventures. Journal of International Business Studies, 37(5), pp. 713-731.

Coviello, N. and Munro, H. (1995). Growing the entrepreneurial firm: Networking for international market development. European Journal of Marketing, 29(7), pp. 49-61.

Crick, D. (2009). The internationalization of born global and international new venture SMEs. International Marketing Review, 26(4-5), pp. 453-476.

Di Gregorio, D., Musteen, M. and Thomas, D. (2008). International new ventures: The cross border nexus of individuals and opportunities. Journal of World Business, 43(2), pp. 186-196.

De Clercq, D., Sapienza, H. J., Yavuz, R. I. and Zhou, L. (2012). Learning and knowledge in early internationalization research: Past accomplishments and future research directions. Journal of Business Venturing, 27(1), pp. 143-165.

Garcia-Cabrera, A.M., Garcia-Soto, M.G. and Suarez-Ortega, S.M. (2017). Macro-level spillovers and microlevel capabilities as antecedents of young SMEs' propensity to export and to become a born global. International Entrepreneurship and Management Journal, 13(4), pp. 1199-1220.

Hashai, N. (2011). Sequencing the expansion of geographic scope and foreign operations by "born global" firms. Journal of International Business Studies, 42(4), pp. 995-1015.

Jones, M.V., Coviello, N.E. and Tang, Y.K. (2011). International entrepreneurship research (1989_2009): A domain ontology and thematic analysis. Journal of Business Venturing, 26(6), pp. 632-659.

Karra, N., Phillips, N. and Tracey, P. (2008). Building the born global firm: Developing entrepreneurial capabilities for international new venture success. Long Range Planning, 41(4), pp. 440-458.

Kontinen, T. and Ojala, A. (2010). Internalization pathways of family SMEs: Psychic distance as a focal point. Emerald, 3, pp. 437-454.

Lockett, A., Moon, J. and Visser, W. (2006). Corporate social responsibility in management research: Focus, nature, salience and sources of influence. Journal of Management Studies, 43(1), pp. 115-136.

Luostarinen, R. and Gabrielsson, M. (2002). Globalization and global marketing strategies of born globals in SMOPECs. Annual Conference of the European International Business Academy. Athens.

Martin, S.L., Javalgi, R.G. and Cavusgil, E. (2017). Marketing capabilities, positional advantage, and performance of born global firm: Contingent effect of ambidextrous innovation. International Business Review, 26(3), pp. 527-543.

Moen, O. and Servais, P. (2002). Born global or gradual global? Examining the export behaviour of small and medium-sized enterprises. Journal of International Marketing, 10(3), pp. 49-72.

Mohammed, N., Abaho, E., Sudi, N. and Kusemererwa, C. (2017). Internationalisation of SMEs: Does entrepreneurial orientation matter. World Journal of Entrepreneurship, Management and Sustainable Development, 13(2), pp. 96-113.

Pitan, O.S. and Adedeji, S.O. (2012). Skills mismatch among university graduates in the Nigeria labour market. US-China Education Review, 1, pp. 90-98.

Rasmussen, E. and Madsen, T. (2002). The born global concept. EIBA Conference. 
Rodriguez-Serrano, A. and Martin-Armario, E. (2017). Born-global SMEs performance and dynamic absorptive capacity: Evidence from Spanish firms. Journal of Small Business Management, 1(1), pp. 1-29.

Sulina, K. and Manjit, S.S. (2014). Internationalisation of born global firms: Evidence from Malaysia, Journal of the Asia Pacific Economy, 19(1), pp. 101-136.

Windsor, D. (2006). Corporate social responsibility: Three key approaches. Journal of Management Studies, 43(1), pp. 93-114.

Yu, J., Gilbert, B. and Oviatt, B. (2011). Effects of alliances, time, and network cohesion on the initiation of foreign sales by new ventures. Strategic Management Journal, 32(4), pp. 424-446. 